University of South Florida

DIGITAL COMMONS

Digital Commons @ University of

@ UNIVERSITY OF SOUTH FLORIDA

South Florida

Government and International Affairs Faculty

Publications

Government and International Affairs

2012

\title{
The Global Social Forum Rhizome: A Theoretical Framework
}

Peter N. Funke

University of South Florida, pnfunke@usf.edu

Follow this and additional works at: https://digitalcommons.usf.edu/gia_facpub

Part of the International Relations Commons

\section{Scholar Commons Citation}

Funke, Peter N., "The Global Social Forum Rhizome: A Theoretical Framework" (2012). Government and International Affairs Faculty Publications. 119.

https://digitalcommons.usf.edu/gia_facpub/119

This Article is brought to you for free and open access by the Government and International Affairs at Digital Commons @ University of South Florida. It has been accepted for inclusion in Government and International Affairs Faculty Publications by an authorized administrator of Digital Commons @ University of South Florida. For more information, please contact digitalcommons@usf.edu. 
Global Social Forum Rhizome - Funke

\title{
The Global Social Forum Rhizome: A Theoretical Framework
}

Peter Nikolaus Funke

University of South Florida

pnfunke@usf.edu

\begin{abstract}
Drawing on Deleuze \& Guattari's image of the 'rhizome', this article develops a framework for mapping and understanding the global social forum process and its implications for the broader global left. The image of the rhizome is insightful to analytically accentuate the nature and workings as well as the challenges and contemporary shortcomings of the social forum process and more generally the broader global movement(s). Thriving on multiplicity and thus lacking a dominant core, center or axis, the rhizome emphasizes the multi-connectivity and heterogeneity of this process, which lacks a central actor, issue, strategy or ideology beyond opposition to neoliberalism. What this article suggests to call the 'Global Social Forum Rhizome' provides the texture and infrastructure for a diversity of groups and networks of the alter-globalization movement to come together and to do so without fear for their autonomy, without the need to agree on any kind of programmatic and binding positions or to submit to an overriding or superior struggle, actor or strategy. While the Global Social Forum Rhizome allows for unprecedented connections as well as tempering and managing of the inherent antinomies of the alter-globalization movement(s), its logic at the same time limits the degree of congealed and resilient movement building. The integral characteristics of the rhizome foster a rather thin articulation of commonalities and convergences, which results in a politics that is often unable to move beyond mere symbolic acts and resistances and towards a politics of organizing and concrete movement building.
\end{abstract}

Keywords: Social movements, World Social Forum, rhizome, capitalism, neoliberalism class, alter/anti-globalization movements, global justice movement. 
Global Social Forum Rhizome - Funke

\section{Introduction: ${ }^{i}$}

The success of the first World Social Forum in January of 2001 in Porto Alegre Brazil triggered a dynamic and variegated process. This unprecedented global gathering of social movements, networks, unions, non-governmental and other civil society organizations opposed to neoliberal capitalism spurred the organizing of various editions of the annual World Social Forum ${ }^{\mathrm{ii}}$ as well as countless autonomous regional, national, local and thematic social forums. Based on a peculiar organizational matrix that stresses selforganized, non-hierarchical, open meeting spaces, social forums have been organized on all five continents, ${ }^{\text {iii }}$ in various regions (e.g. Maghreb Social Forum, the Mediterranean Social Forum, the Midwest Social Forum (USA), Southern African Social Forum), multiple national settings (e.g. Brazil Social Forum, Chile Social Forum, Danish Social Forum, Social Forum in Germany, ${ }^{\text {iv }}$ US-Social Forum in Atlanta in June 2007), countless localities (e.g. Berlin, Chicago, Genoa, Houston, Quebec, Rio de Janeiro, or Sydney) and around thematic axis (e.g. Boarder Social Forum in Juarez, Migration Social Forum).

As such, the first World Social Forum in 2001 generated a manifold and heterogeneous 'global social forum process.' Left groups and movements from around the world have been meeting and discussing, interlinking and strategizing at innumerable local, regional and global social forums through workshops, panels, testimonies, seminars, or round tables, at cultural events and through on-site marches and rallies. While most of these forums are explicitly based on the World Social Forum Charter of Principles and considered a vital 'part of a process of construction and universalization of the World Social Forum', ' they are self-organized, autonomous events that do not stand in any hierarchical or subordinate relationship to the World Social Forum and its International Council. ${ }^{\text {vi }}$ Moreover, as social forums are organized in various parts of the world, they take on different dynamics, contingent on time and space. As Janet Conway points out with respect to the World Social Forums, '[w]herever the world event is organized, it enacts its own culturally-specific, geographically rooted social movement processes’ (2005). ${ }^{\text {vii }}$

The variegated nature of this process extends to the uneven actualization, expansion and maturing of social forums. While the social forum process seems to be alive in the Americas and modestly growing in Africa, it is in particular the European social forum process that appears to be stalling and possibly entering a phase of introspection as numbers of social forum participants are declining and social forums themselves are becoming defunct. In sum, the multifariousness of the global social forum process with its myriad of time and space contingent forums on local, national, regional, and global levels confounds easy legibility and classification.

Analyzing, classifying, and theorizing the political, social movements or social forums is ultimately done from a particular vantage point. 'Theory', as Robert Cox reminds us, 'is always for someone and for some purpose' (1981, p. 128; emphasis in original). The following is thus an interpretation and argumentation, which imposes representations, concepts and theories onto the world from a particular culturally enabled, socio-politically framed perspective. More specifically, from a (European, youngish, male) neo-Marxist ethnographer who is sympathetic to many of the alter-globalization movement's goals. 
While recognizing these challenges, in the following I develop a framework that is conceptually useful for mapping and understanding this kaleidoscopic global social forum process and its implications for the broader global left. Throughout this article I draw on the growing social forum literature, which includes informative, early compilations (Fisher \& Ponniah, 2003), pioneering empirically focused accounts (e.g. Smith et. al., 2008), diverse and variegated descriptions (e.g. Leite, 2003), analysis (e.g. Whitaker, 2007) or conceptualizations (e.g. Pleyers, 2004; Sousa-Santos, 2006), including broad ranging, captivating and insightful edited volumes (Sen et al., 2008; Blau \& Karides, 2008). This article and my broader project seeks to add to this body of work. Based on years of participant observations at various social forums (local to global), including virtual ethnography as well as interviews with activists and organizers I seek to advance a yet missing larger theorization and more comprehensive analytic framework on the social forum phenomenon writ large.

Drawing on Deleuze \& Guattari, I suggest that the image of the 'rhizome' is insightful to analytically accentuate the nature and workings as well as the challenges and contemporary shortcomings of the social forum process and more generally the broader global movement(s). Thriving on multiplicity and thus lacking a dominant core, center or axis, the rhizome emphasizes the multi-connectivity and heterogeneity of this process. What I am calling the Global Social Forum Rhizome lacks a central actor, issue, strategy or ideology beyond opposition to neoliberalism. This common opposition, however, suggests a rudimentary system of interactions of this segmented and decentralized organizational formation. Like the 'mass of roots', which connect and thus generate a rhizome, the Global Social Forum Rhizome too provides the texture and infrastructure for groups and movements from various parts of the world and of different sizes, scales, issues or strategic outlooks to interact with any other. For instance, through social forums, global environmental networks, German labor unions, Amazonian fisherfolk and human rights groups from cities in North America are learning about each others' existence and struggles. Since the first World Social Forum, they have been connecting and coordinating their efforts related to an aluminum production process that runs from the Brazilian Amazon to Northern Europe. viii

The rhizomatic nature of the global social forum process thus allows for the diversity of constitutive groups and movements of the alter-globalization movement ${ }^{\mathrm{ix}}$ to come together and to do so without fear for their autonomy, without the need to agree on any kind of programmatic and binding positions or submit to an overriding or superior struggle, actor or strategy. The core characteristics of the Global Social Forum Rhizome are aimed at protecting the independence of each group and movement and thus their diversity taken as a whole, while at the same time providing for a possibility to articulate and enact linkages, commonalities and convergences.

The ensuing connections, however, are not without drawbacks, which the concept of the rhizome also helps to analytically unearth, represent and understand. While the rhizomatic texture arguably allows for unprecedented connections as well as tempering and managing of the inherent antinomies of the alter-globalization movement(s), its logic at the same 
time limits the degree of congealed and resilient movement building. ${ }^{\mathrm{x}}$ The integral characteristics of the rhizome foster a rather thin articulation of commonalities and convergences, which results in a politics that is often unable to move beyond mere symbolic acts and resistances and towards a politics of organizing and concrete movement building.

The logic of the Global Social Forum Rhizome is thus a double-edged sword. As I argue elsewhere, it lends itself well to operate as 'resistance relay' for the alter-globalization movement(s), generating contacts, linkages and awareness of the various struggles without encroaching on the independence of groups and movements. This rhizomatic logic that allows and shields diversity is at the same time less able to function as 'organizational relay' for building a consolidated movement. The latter would arguable require transversal mechanisms and structures that would trigger processes of generating new synthesis across movements and group. ${ }^{\mathrm{xi}}$

While this article will revisit these challenges, I focus in the following on developing the conceptual framework of the Global Social Forum Rhizome. After introducing the neoliberal context and the protests moments and cycles (Reitan, 2007; Tarrow, 1998 \& 2005) out of which the World Social Forum emerged, this article introduces the concept of the rhizome to structurally map and delineate the World Social Forum and the process it has sparked. I enumerate core characteristics of the Global Social Forum Rhizome and its implications for the broader global movement(s).

\section{Neoliberal Capitalism and the emergence of the World Social Forum}

The World Social Forum and the social forum process it has triggered across the world emerged from the recent mobilizations and protests against the implementation of global neoliberal restructuring policies that began to consolidate in the 1970s in the global south. Since then, economic growth strategies have globally prescribed market driven approaches based on privatization, deregulation and liberalization (Harvey, 2005/2007, pp. 3). The policies include the commodification of publicly or communally owned industries, services, and resources including water and land as well as the deregulation and liberalization of trade in goods and services. These neoliberalization dynamics have expanded and deepened the scope of the capitalist commodification and profit logic, which increasingly goes beyond the strictly economic realm and encroach on cultural, ecological, and formerly public and societal spheres such as education, retirement, or health care.

The transformations of the global political economy are in turn generating modified capital and class relations and thus restructure the composition of struggles and movements as well as their practices and strategies (Funke, 2012; Funke, Robe \& Wolfson, forthcoming). These dynamics have been fragmenting and at the same time broadening the collectivity of progressive groups and movements resisting neoliberalizing capitalism. The center of resistance is no longer predominately comprised of exploitations on factory floors and at conveyer belts but includes increasing numbers of service sector workers or students as well as oppressions structured by gender, race, or sexual orientation. As such, class has to be reconceptualized to include other experiences and other social subjectivities, 'which 
constitute the current expression of the conflict between labor and capital' (Lorenzano 1998, pp. 132-133, Funke). As I argue elsewhere in more detail, the increasing existence and recognition of these various forms of oppression is nevertheless objectively shaped by neoliberal capitalism and class relations (Funke, forthcoming). Patriarchy and racism, for example are to a certain degree restricted hierarchies whereas class relations are part of all capitalist formations and social groups, constituting a common structure of exploitation underneath the particular one of, for instance, patriarchy and racism (Dyer-Witherford, 1999). In fact as I will suggest below, avoiding the structuring power of capitalism and class relations help to account for the unstable and voluntaristic nature of the current movement cycle as illustrated most recently by the 'Occupy Wall Street' protests.

In addition to these structural imperatives, the organizational history of the left itself generates the need for novel processes and linkages among this more extensive but also increasingly heterogeneous and splintered grouping. In particular the failures of the state socialist projects made groups and movements of the left 'wary of any group playing a vanguard role in defining the society that the overall global movement should pursue' (Fisher \& Ponniah, 2003, p. 13) while recognizing the need to 'articulate a common vision' (ibid.). As I shall suggest in this article, rhizomatic organizational constellations are emerging that enable configurations which seek to safeguard the heterogeneity and the groups' autonomy while at the same time recognizing the need to bridge and congeal left groups and movements into new formations.

Accordingly new resistance, frequently with an innovative political character emerged, which influenced the formation of the alter-globalization movement in general and the World Social Forum in particular (Leite, 2003, pp. 41). Specifically, the Zapatista uprising in Chiapas, Mexico that went public and issued their first declaration on the day the North American Free Trade Agreement came into effect on January 1, 1994 and the anti-World Trade Organization protests in Seattle in 1999 that shut down the Ministerial Conference arguably provided two of the most direct influences for organizing the first World Social Forum in January of 2001. ${ }^{\text {xii }}$

While the Seattle protests were important in that they became a symbolic marker in the global north and thus consolidated the global resistance to neoliberal policies (Leite, 2003, pp. 55; Burbach, 2001, pp. 23) it was the Zapatista with their radically democratic and pluralist approach that prefigures much of what would become the social forum logic. The Zapatista outlook is epitomized in their slogan 'one no and many yeses,' capturing the unified 'no' to neoliberalism while acknowledging the diversity and plurality of alternatives, needs, aspirations, tactics or ways of living and doing (Midnight Notes, 1998). ${ }^{\text {xiii }}$ This perspective arguably undergirds social forums' own self-understanding of collectively rejecting neoliberalism while embracing a plurality of alternative worlds thus allowing for linkages and convergences while guaranteeing the groups' autonomy. Moreover, the various International Encuentros of the Zapatista with 'the People of the World', which have taken place since 1996 have foreshadowed core organizational dimensions of social forums such as their emphasis on radical democracy and selforganization as well as autonomy and diversity. ${ }^{\text {xiv }}$ 
As such, the World Social Forum was 'born Latin', as Isabelle Biagiotti put it (2004, p. 536). Born Latin not only because it was an invention of mainly Latin American and to a lesser degree Southern European activists but also because the World Social Forum recalibrates relations between groups and movements of the global north and south. Emancipatory efforts during the Cold War such as the various international solidarity movements including the Third World solidarity movements were arguably characterized by mostly one-way flows of ideas, resources and solidarity from the allegedly richer, stronger first world activists to the poor and more passive recipients in the third world. ${ }^{\mathrm{xv}}$ With the Zapatistas and the World Social Forum phenomena this relationship has become more reciprocal and mutual. Organizational ideas, practices, and strategies, including the emphasis on participatory democracy as a vital part and engine of socio-economic change, the belief that radical change has to emerge from below, and the recognition that the multiple facets of exploitation have to be fought everywhere not only in Chiapas or the Niger Delta but also in Philadelphia and Berlin. ${ }^{\text {vvi }}$

\section{The First World Social Forum}

The World Social Forum in name, place and approach was conceived of as a counter-event to the World Economic Forum, which annually brings together the global elites in Davos, Switzerland. Seeking to improve upon the organizationally challenging anti-World Economic Forum protests in Davos from the mid-1990s (Cassen, 2003), emphasizing the social instead of the economic in its name, and meeting in Latin America where the failures of neoliberal policies might have become most obvious, the World Social Forum contrasts starkly with the European-based World Economic Forum. The latter meets under heavy security in the mundane ski resort Davos in the Swiss Alps and restricts participation to the few elites of politics, business and culture whereas the World Social Forum is open to almost anyone.

With the crucial political and organizational support by the Brazilian Workers' Party run state of Rio Grande do Sul and the city of Porto Alegre, the first World Social Forum took place in January of 2001. Under the slogan 'Another World is Possible', roughly 4,000 delegates, 16,000 registered participants from 117 countries, 1,870 journalists (with 386 foreigners), as well as an unknown number of walk-in participants attended. They participated in 16 plenary sessions, about 400 workshops, and 20 testimonials, and a large number of autonomous activities, held simultaneously in the city, such as the World Parliamentary Forum, the Forum of Local Authorities for Social Inclusion, the Intercontinental Youth Camp (with circa 2400 participants), the Indigenous Peoples Camp (with about 700 participants) and many parallel meetings, marches, demonstrations, concerts, cultural activities, and parties. World Social Forums are chaotic and consuming, invigorating and optimistic. Michael Hardt has described it in terms of 'its overflowing enormity [where an] overabundance created an exhilaration in everyone at being lost in a sea of people from so many parts of the world who are working similarly against the present form of capitalist globalization' (2002, p. 112).

This first World Social Forum symbolized for many something new and important. As a Berlin-based activist put it '[t]he hope was that the social forum idea was a novel attempt 
to bring together diverse political and social groupings' (Bahn \& Haberland, 2003, p. 31). Unanticipated, the first World Social Forum transformed into something much larger. Not only was the attendance by delegates from movements and organizations almost double of what was expected but it also started a global social forum process. While the annual World Social Forums have grown three to seven-fold, ${ }^{\text {xvii }}$ the social forum idea and matrix 'globalized'. In a seemingly paradoxically top-down or rather global to local fashion, countless autonomous regional, national, local and thematic social forums have sprung up, generating a 'global social forum process'. The social forum idea, this 'first step, but an entirely new step', according to Chico Whitaker, was increasingly, 'finding an echo the whole world over' and, so the Brazilian World Social Forum co-founder hoped, would 'secure the beginning of a new period in the struggle against human submission to the interest of capital' (2002).

Indeed, the World Social Forum echo was quickly taken up. Forums have been organized on all continents, in regional and national contexts as well in countless local setting. Berlin based activists, for instance, came back from the first European Social Forum in Florence in 2002 with the ambition to create something similar in Berlin and to thus transfer or adapt their European Social Forum experiences to the local Berlin setting. As one of the activists pointed out' [t]here was a general sentiment of take off: Florence was decisive for the creation of the Social Forum in Berlin. ... In Florence, we realized that the globalization-critical Left only has a chance if we come together' (Bahn \& Haberland, 2003, p. 31). Another activist of the Berlin Social Forum argued similarly that ' $[\mathrm{t}] \mathrm{he}$ experiences of the past social forums were central. We have to move out of our "smallsmall.” If left politics should have impact, we have to stop working against one another. No social actor is able to do something against the neo-liberal onslaught by himself. Not the churches, not the unions, not ATTAC - no one alone' (ibid., p.31).

For the local and regional forums that emerged, the 'global birthplace' of the social forum process is significant. It recognizes the importance of the global political economy for the national and local contexts. From the start in 2001, a central characteristic of social forums has been that '[o]rganizations whose horizons have in the past been limited to the nation, or the locality have found themselves connecting with groups engaged in similar struggles across national borders' xviii The Berlin Social Forum in the spring of 2007, for instance, aimed to embed its events in the broader European and global social forum processes. Structuring themes were related to the Group of Eight meeting in Heiligendamm, Germany in the summer of that year. One of the principle themes of the Berlin Social Forum were 'why and how does the G8 summit have anything to do with Berlin.' The idea was, as one organizer put it, to 'bridge the local and the global. G8 politics are fucked up [...] and they massively impact Berlin politics.' In addition, the Berlin Social Forum set up a one and a half hour teleworkshop with the Social Forum in Ivry, ${ }^{\text {xix }}$ a suburb of Paris to link different localities and struggles with the European and global political economy. The earlier social forum process had been instrumental as several activists and participants from Berlin and Ivry had already met at workshops of local social forums at the European Social Forum in Athens in 2006 as well as at the World Social Forum in Nairobi in 2007 and are active participants in the 'Network of Local Social Forums'. 
Striving to go beyond the more reactive mobilizations and protests at meetings of international institutions and forums such as the International Monetary Fund, the World Trade Organization, the Group of Seven, Eight or Twenty or the World Economic Forum, the first World Social Forum in 2001 set a pattern of how movements, networks, organizations and groups around the world can come together. Hoping to withstand the ebb and flow of protest cycles, ${ }^{\mathrm{xx}}$ many social forums that have been organized on local, national or regional levels echoed the organizational form of the World Social Forum event: self-organized, non-hierarchical, open meeting spaces for discussion, linkages and convergence of the diversity of left emancipatory groups and movements from around the world that are 'opposed to neo-liberalism and to domination of the world by capital and any form of imperialism' (Principle 1 of the World Social Forum Charter). During these often multi-day events various groups and movements come together in conferences, workshops, testimonies, seminars, press conferences, panel debates, and round tables. These events are often supplemented by a cultural program, demonstrations and protest marches.

The autonomous, open nature of social forums makes them contingent on time and space. As the social forum idea is taken up in different locations and contexts, it adapts and transforms. As Janet Conway writes with respect to the World Social Forum in general and the 2007 World Social Forum in Nairobi in particular 'I have sought to problematize treating the World Social Forum, as event or process, as a single thing, an undifferentiated whole. Instead, I have advocated recognizing the plurality of the spaces, places and differences that constitute the World Social Forum, both as event and as a global process' (2008, p. 69).

Social Forums are time and space dependent and the World Social Forums in Porto Alegre in 2002 or 2005, in Mumbai in 2004, or 2007 in Nairobi and 2011 in Dakar are not duplicates. The musicological term 'variation' might be helpful in capturing the commonalities and differences when social forums travel in time and space. Like variations or more specifically so-called 'Fantasia Variations' where musical material is altered and repeated in a different manner during repetition while the fundamental musical idea is unaltered, social forums are time and space dependent and vary greatly but seem to always encompass or 'repeat' core principles. ${ }^{\text {xxi }}$

The remainder of this article draws on the Deleuzian \& Guattarian concept of the rhizome to develop a framework that aids us in analytically approaching the global social forum process. It helps addressing these 'core principles', social forums' fundamental ideas that get 'repeated' through time and space as well as challenges and shortcoming of this particular social movement logic.

\section{The Global Social Forum Rhizome: Developing a Framework}

The account above has already suggested the messy, abounding nature of the global social forum process, interspersed by geographic, temporal, cultural, and socio-political differentiations and variations. The following begins to develop the rubric of the 'Global Social Forum Rhizome' to conceptually map and analyze the dynamic texture and praxis 
of this uneven global social forum process as well as its challenges for sustained organizing and movement-building.

There are two principle ways in which the 'rhizome' is useful for understanding the global social forum process and the alter-globalization movement in general: as an epistemology and as a conceptual framework. Epistemological, the rhizome provides a particular way of approaching and studying social forums, while the rhizome as conceptual framework can help us to better understand the global social forum process and its implications. ${ }^{x i i}$ The following focuses on the rhizome as conceptual framework for the global social forum process.

I borrow the term rhizome' from Deleuze \& Guattari who use it to describe singularities that interact to form a multiplicity. That is to say a unity that is multiple in itself. '[T]he rhizome connects any point to any other point', Deleuze \& Guattari write, 'and its traits are not necessarily linked to traits of the same nature [...] the rhizome pertains to a map that must be produced, constructed, a map that is always detachable, connectable, reversible, modifiable, and has multiple entranceways and exits' (1980, p. 21). Moreover and despite the botanical connotation, like plants of rhizomes, each detached piece can generate a new rhizomatic structure (ibid., p. 519).

Transposing the rhizomatic image helps to conceptualize the global social forum process. The latter is made up of and constructed by singularities (e.g. groups, networks but also individual social forums themselves) of various scales (e.g. smaller groups such as individual organizations or unions and global networks such as the peasant network Via Campesina) that interact on multiple levels (local to global) and through time. The concept of the rhizome thus 'suggests networks of heterogenous elements that grow in unplanned direction, following the real-life situations they encounter' (Escobar, 2004, p. 352).

Rhizomes need open and unstructured spaces. The Global Social Forum Process relies on a politics of open-space and inclusiveness. The only precondition for participation is to abide by the deliberatively vague principles set out in the Charter, which defines a social forum as an 'open meeting place for reflective thinking, democratic debate of ideas, formulation of proposals, free exchange of experiences and interlinking for effective action, by groups and movements of civil society that are opposed to neo-liberalism and to domination of the world by capital and any form of imperialism. ${ }^{\text {xxiii }}$

More specifically, three closely related and reciprocal characteristics of the rhizome are particularly useful for understanding the social forums process: its multi-connectivity, heterogeneity, and multiplicity. I shall discuss each of those below.

\section{Multi-Connectivity}

Rhizomes are characterized by their connectivity. 'Any point', Deleuze \& Guattari write, 'of a rhizome can be connected to anything other, and must be. This is very different from the tree or root, which plots a point, fixes an order' (Deleuze \& Guattari, 1980, p. 7). Unlike a tree structure, with only one path from one particular point to any other point, 
rhizomes represent non-hierarchical structures where any point can connect to any other point, generating links that can stretch - unevenly and asymmetrically - across spaces, and times, scales, issues or strategies. As such rhizomatic structures have 'multiple entranceways and exits' (Deleuze \& Guattari, 1980, p. 21). Unlike a tree-structure with its 'root node' or starting point and end-points or 'leave nodes', rhizomatic structures can be entered and exited from any point. Analogously, the social forum process has multiple 'entranceways', is constructed and produced, reversible and modifiable. For example, unlike more focused meetings of trade unions, human rights networks, environmental conference or indigenous rights forums, the Global Social Forum Rhizome brings together these diverse actors. A more exclusive meeting of unions or human rights activists is less likely to generate these sorts of contacts. A social forum participant emphasized, that organizing a workshop at social forum, 'you never know who might show up [...] people that you would otherwise never get at one table [...] people that prior to the forum have not been aware of each other [...] a unionist from Nigeria comes, and one from Thailand and another from Indonesia with which you would not have any contacts through the official channel $[. .$.$] this possibility to create networks we do not have otherwise.'$

Moreover, social forums themselves are rhizomatically connected. They do not stand in subsidiary relations to one another and thus do not reflect a 'matryoshka doll'. A local forum, such as the Berlin Social Forum, is not nested in and subordinate to the German Social Forum, which itself does not fold into the European Social Forum and the latter does not defer to the World Social Forum. Rather the various levels are interlinking asymmetrically, generating and at the same time using the Global Social Forum Rhizome.

Consequently, participation in social forums does not necessarily overlap. That is to say, some groups and individuals might be active on the World Social Forum level but not on the continental, national or local level. The reasons are arguably manifold. For instance groups in the global north that work on development use the World Social Forum event to link up with their partners in the global south. ${ }^{\text {xxiv }}$ They often do not see any reason for attending, for instance, the European Social Forum or local social forums. 'If church-based aid networks meet with their partners from the developing world at the World Social Forum they have no clue what to do at the European Social Forum', Philip Hersel from Blue 21, a Berlin-based environmental and development organization, points out, 'on the European level this [aid work] is not really an issue. There are then other church groups, I don't know, immigration groups for example, who naturally are more interlinked and networked on the European level, Fortress Europe and so forth. ${ }^{\text {xxv }}$ Similarly, local social forum participants often do not have the resources for or see the benefits in participating in continental or the World Social Forum. The multi-connectivity of the Global Social Forum Rhizome thus fosters linkages of diverse participants, groups or networks. This heterogeneity is a second characteristic of rhizomatic structures.

\section{Heterogeneity}

The social forum fostered rhizomatic connections are not only between similar or cascading elements such as tree roots, who anchor the main stem structure which has apical dominance. Rhizomes enables 'things of differing status' (Deleuze \& Guattari, 1980, p. 7) to connect. As such, social forums can bring together large actors such as labor 
unions with smaller communities of fishermen or indigenous groups or direct action networks with more traditional advocacy organizations and groups that focus on different issue such as the environment, gender inequality or fair trade.

For instance, the Confederation of German Trade Unions (DGB), the umbrella organization of several trade unions representing roughly seven million members, for instance, interacts with members of environmental networks, local fishermen, peasants and indigenous groups at the social forums to work, as Manfred Brinkman, a coordinator for political education with the Confederation of German Trade unions (DGB), explains on issues related to Brazilian aluminum. The production lines starts from the mining factories of Albras (Alumínio Brasileiro S.A.), the second-largest aluminum producer in Brazil, and Alunorte (Alumina do Norte do Brasil, S.A.) in the Amazon and leads to the refineries in Belém where the aluminum oxides are obtained. It is then shipped to the Global North where it is processed for the end products. Multiple environmental as well as social problems emerge along this production line. ${ }^{\text {xxvi }}$

The World Social Forum served as the contextual environment for these linkages, bringing together the individual-and otherwise isolated-groups effected by this production process; effected, however, not in the same issue area but rather coming to it from different angels. The inclusiveness and openness that defines social forums allows for the coming together of these divers actors-something that a more focused meeting, for instance a union meeting, a forum focused on indigenous rights, or an environmental convention would have been less likely to accomplish. Similarly, the rhizomatic texture provided the context for global-local linkages, which this example highlights.

The example of the aluminum production chain brings forth the third core characteristic of the Global Social Forum Rhizome. Rhizomatic structures are marked by their multiplicity.

\section{Multiplicity}

The Global Social Forum Rhizome is defined by its multiplicity. Its entities, such as constitutive groups but also individual forums are irreducible and 'ceases to have any relation to the One [...] image and world' (Deleuze \& Guattari, 1980, p. 8). Concomitantly, social forums reject 'the one' and rather embrace the multiplicity that operates without a central actor or political protagonist - a multiplicity and diversity of indivisible actors, where indigenous, environmental, feminist or labor movements are all essential.

This multiplicity includes the bringing together of diverse movement traditions (including the labor movement, new social movements, indigenous and peasant movements) and operating levels (ranging from neighborhood groups, city and regional projects to global networks) from the Global North and South. The reciprocal relationship between the rhizomatic infrastructure and its diversity indicates a potentially new kind of political formation. As Janet Conway notes, '[i]t is this extraordinary paradox, that embracing diversity is producing unprecedented coordinated action on global and local scales, that is key to the generative power of the Social Forum and suggestive of a new democratic, decolonized and decolonizing politics on a world scale’ (2005, p. 427). 
The rhizome's multiplicity applies similarly to the range of issues, strategies, and alternatives. As such, social forums seek to bring out, embrace and link a range of different substantive foci (e.g. groups that work on anti-racism, the environment, indigenous struggle, labor issues, media democracy, or gender equality), tactics and strategies (e.g. holding counter-summits; organizing demonstrations, non-violent direct action and (symbolic) property destruction) medium-term objectives (e.g. documenting and reporting; conducting specific welfare enhancing activities and programs; establishing autonomous zones, social and workers centers; building networks and movements) and long-term horizons (e.g. systemic reform or revolution). Social forum thus, stands in opposition to what the editor in chief of Le Monde Diplomatique and member of ATTAC, Ignacio Ramonet has called the 'pensée unique', the 'single thought' of mainstream thinking where there is supposedly no alternative to neoliberalism (1995).

The multiplicity of rhizomatic structures also extends to the ability to attempt to alter temporalities. Achim Neumann who is a shop steward with Ver.di, focusing on work precariousness, recalls his experience from the 2006 European Social Forum in Athens. ${ }^{\text {xxvii }}$ In Athens he organized a panel and information stands on Lidl. Lidl is one of Europe's biggest discount supermarket chains based in Germany. Lidl has about 74,000 stores in 23 European countries and generated a profit of Euro 40 billion in 2005. Lidl's labor relations are widely criticized for putting great pressure on its workforce to, for instance work overtime and prevent any worker organizations. ${ }^{\text {xxviii }}$ At the European Social Forum in Athens, Neumann recounts, 'many came to us and have asked what is going on? In particular people from Turkey who I have never met before and would not have known of [...] and they found out about Lidl, who is not in Turkey yet. These were very interesting encounters with people who said we definitely want to keep on being informed about what is happening because we are sure that in the near future, Lidl will also come to Turkey and then we want to be ready for them. So, I think what is happening already is great; they act before they have to react once the joint is there and normally they open with 15, 20 or 25 branches at the same time'. xxix

The Lidl-Campaigners and activists in Turkey, which had no prior connection to each other, used the European Social Forum to interlink. Through these contacts groups and movements in Turkey are able to learn from experiences in other places and times to proactively design a strategy to counter, in this case, Lidl's poor labor relations before Lidl has descended upon Turkey. This example indicates that rhizomatic structures enable the recognition and operation of these organizers, unionists and activists on the plane of time. ${ }^{\mathrm{xxx}}$ The characteristics of rhizomatic structures that eschew hierarchy and linearity allows Turkish activists to 'overleap time', to engage politically with as of yet unrealized threats by connecting at and through social forums.

\section{Accomplishments \& Limitations of the Rhizome}

On the basis of the rhizomatic infrastructure with its unique organizational matrix, social forums have arguably been successful in producing awareness, connections and mobilization around the globe. Put differently, the Global Social Forum Rhizome functions as 'resistance relay', by acting as catalyst and generating linkages, mobilizations and 
convergences of the multi-centered global movement(s) (Funke, 2008). Moreover, social forums have been instrumental in holding the diversity of the global left together. As Ruth Reitan points out, a distinctive characteristic about the 'present moment is the degree to which the global left has not fractured into its historical constituent parts of liberalism, Marxism, and anarchism-autonomism' (2011, pp. 52). ${ }^{\text {xxxi }}$ While the overall weakness of the global left arguably plays a role, the Global Social Forum Rhizome has been a crucial element for this unprecedented degree of contact of the various wings of the global left.

While its peculiar organizational structure has buttressed these centripetal dynamics, the rhizomatic matrix and logic of social forums is also riddled with tensions and challenges. The degree of its integrable dynamics are in part generated through a lack of coherent goals and strategies. While the organizational limitations of openness and horizontality, diversity and consensus decision making that defines the anti-globalization movement in general and the Global Social Forum Rhizome in particular, prevent a deeper fracturing of the global left, its rhizomatic structure at the same time tends to lead to transient networks that present challenges to movement building and long-term growth.

The contemporary rhizomatic logic allows for the coming together and networking of the various constitutive parts of the global left as it safeguards the groups' and movements' diversity and autonomy. The results though cater towards a politics of resistance that eschews institution- and movement-building as well as sustained organizing (Epstein, 1991). The image of the rhizome is insightful here as well as it denotes something that it is always in the middle, grows in unplanned ways. Deleuze \& Guattari write that '[a] rhizome doesn't begin and doesn't end, but is always in the middle, between things, interbeing, intermezzo' (1980, p. 519). It suggests an 'unplanned', un-strategized or at least understrategized direction. By its very nature, the rhizome lacks 'genetic axis or deep structures' or what Deleuze \& Guattari enumerate as the rhizomes' principles of 'cartography and decalcomania' (1980, p. 12) that can bind the alter-globalization movement in more incessant formations. The iconic diversity of the alter-globalization movement in general and the principled safeguarding of the groups' and movements' autonomy as well as the resulting cacophony alludes to barriers for strategizing and sustained movement building. The contemporary weakening or possibly waning of the alter-globalization movement might be due to the challenges inherent in such a rhizomatic logic for building resilient, potent movements. The rhizoma, the rhizome's 'mass of roots' makes it demanding to work through diversity and difference and toward new synthesis. For organizing and movement building it needs more concerted efforts to produce sustainable commonality and agreements for which leadership development is crucial and a certain degree of hierarchy necessary. That is to say, in order to generate a process of 'becoming other together' it needs mechanisms for decision-making that approach differences not as absolutes but rather as something 'to work through and coming up with new synthesis' (Nunes, 2006, p. 305).

I suggested above and in more detail elsewhere that it is in particular, the sidestepping of the structuring power of capitalism, which contributes to the transient nature and current weakening of the Global Social Forum Rhizome and the alter-globalization movement. ${ }^{\text {xxii }}$ It is the revolving of structures of domination of, for instance, gender or race, around the 
principles of commodification and profit that gives capital and class relations its pivotal stance (Dyer-Witheford, 1999).

\section{Conclusion:}

The Zapatistas and the Seattle experiences helped trigger the social forum process as an attempt to create spaces where the diversity alter-globalization movement(s) could come together, seek linkages and commonality without fearing for their own autonomy. The first World Social Forum in 2001 has since triggered countless forums to be organized around the globe. The resulting dynamic and variegated global social forum process has been an important infrastructural matrix for the global left. At and through social forums the constitutive groups and movements of the alter-globalization can come together, seek linkages and convergences.

To gain analytic purchase on this multifarious global social forum process, this article suggested the rhizome as a conceptual framework to analytically approach the global social forum process and the alter-globalization movement(s) more generally. The image of the rhizome and the subsequent Global Social Forum Rhizome is well suited to illuminate its multi-connectivity, heterogeneity and multiplicity and instructs us to investigate the Global Social Forum's constructiveness, reversibility and transformability. The rhizome moreover, provides a rubric for analyzing challenges and shortcomings. I suggested that the versatility, malleability or structurless-ness of the Global Social Forum Rhizome, which allows for bringing together the diversity of alter-globalization movements and groups, is also limiting more resilient and sustained movement building dynamics.

By way of conclusion, I want to suggest three avenues for future research. ${ }^{\text {xxxiii }}$ The global social forum process and its rhizomatic nature might be an instantiation of an emerging new stage in left movement based politics, which I suggest to call the 'Rhizomatic Left' (Funke, 2012) ${ }^{\text {xxxiv }}$ While more research is needed, Rhizomatic Left is a helpful marker in that it does describe the emerging Left along its organizational form and its dynamic interaction principles. In ideal-typical terms, the term Rhizomatic Left captures and can thus be set apart from the Old Left and New Left. While the Old Left was hierarchically organized and made up of homogenous elements that 'grew in planned' directions on class basis, the New Left was made up of heterogeneous elements and issues and a prefigurative dynamic for a cultural revolution. The Rhizomatic Left is consciously seeking connections between Old and New Left on the basis of a rhizomatic logic that unfolds on the shared background of opposing neoliberalism while stressing the singularities in the multiplicity of the Left and allowing for time and space dependent transformability and adaptability. The notion of the Rhizomatic Left can mark the diversity of the left writ large since 'rhizome' denotes a heterogeneous multiplicity, allowing us to represent the various strands of the global left, ranging from more prefigurative movement based 'shoots' and 'roots' which arguably dominate at social forums to the statist left of, for instance, the progressive governments in Latin America.

As this article sought to show, however, the contemporary instantiation of a rhizomatic logic has its limitations. I want to suggest that it is in particular the absence of a unifying 
dimension or transversal axis and an orthodox understanding of its organizational model, which might help us to understand the current weakness of the global social forum process and more generally the global left.

The earlier example of the aluminum production line is insightful. The diversity of groups and movements were able to come together and start coordinating sustained organizing on the basis of a common and generalizable struggle. Raymond Williams and later David Harvey suggested the concept of 'militant particularism', which might be helpful. The concept refers to the understanding that struggles and movements are beginning as particular struggles, in particular settings, places and communities. However, the key to the notion of militant particularism is that its inherent characteristics, be it knowledge, practices, skills, and imaginaries, can be generalized, and thus transcend its particularity to be employed across a 'spectrum of specific situations and singular struggles' (Harvey, 1996, p. 33). As Williams put it 'of course almost all labour struggles begin as particularist. People recognize some condition and problem they have in common and make the effort to work together to change or solve it ... the unique and extraordinary character of working-class self organization has been that it has tried to connect particular struggles to a general struggle in one quite specific way. It has set out, as a movement, to make real what is at first sight the extraordinary claim that the defense and advancement of certain particular interests, properly brought together, are in fact the general interest' (1989, p. 249). This thus points to an important dynamic that might serve to guide formations for more resilient and powerful movement. As Williams writes, a militant particular struggle in a specific context also intrinsically carries a kernel, the claim that appropriately bringing together the particularisms of groups and interests are the common interest.

As the aluminum example indicates, the underlying commonality can be seen in the fact that all other structures of oppression (patriarchy, racism, etc.) stand in relation to capital and class relations. The various groups and movements that make up the broader alterglobalization movement as well as those that participate in social forums operate under the capitalist mode of production in that it establishes the respective material conditions of possibility. The existence of the various forms of oppression is shaped by the capitalist mode of production and is situated in the context of capitalist forces and relations that produce it (Gimenez, 2005, pp. 20). Immigrant, women or racial oppression are to a certain degree restricted to their respective particular ascriptive hierarchies. Class relations, on the other hand, are common to all capitalist social formations and social groups, running through for instance women or immigrants and thus providing a common structure of oppression beneath the particular one of, for instance, patriarchy and racism. This would then allow us to identify capital and class relations as a transversal axis, which provides a unifying experience for other structures of domination. As Dyer-Witherford argues, capitalism is distinguishable from other forms of domination such as racism or patriarchy in that only it has succeeded in 'knitting the planet together into an integrated coordinated system of interdependencies with the aid of new technologies [globally mapping] the availability of female labor, migration flows, human gene pools, and entire animal and plant species onto its coordinates of value [thus] subsuming every other form of oppression to its logic. Indeed, it is possible now to see much better than Marx in his day could how 
the capitalist international division of labour often incorporates, and largely depends on discrimination by gender or ethnicity to establish hierarchies of control' (1999, p. 15).

A renewed emphasis on capital and class relations is not to argue that gender or race based oppression can be reduced to the former nor does it imply that structures of domination should not be resisted where they occur. However, it does suggest that oppositional and resistance movements that fight and struggle for women's rights or racial equality reach limits without engaging capitalism.

This brings me to my final suggestion regarding the contemporary organizational model for movement politics that comes out of social forums and the global movements in general. As I sought to indicate, the contemporary social forum process as well as the global alter-globalization movement(s) have been informed and inspired by the Zapatistas. Their 'one no' - to neoliberal capitalism - 'and many yeses' - meaning there are many approaches and alternatives to neoliberal capitalism - undergirds, for instance, the Global Social Forum Rhizome’s own self-understanding.

However, a central dimension of Zapatismo was toned down. The Zapatista's fusing of the more hierarchical, movement-building approach of the Fuerzas de Liberacino National with the horizontal, grassroots and radical democratic experience of the indigenous communities, I suggest, generates a synthesis, which I describe elsewhere as 'heterarchy'. Heterarchy describes the 'the relation of elements to one another when they are unranked or when they possess the potential for being ranked in a number of different ways' (Ehrenreich, 1995, p. 3). The notion of heterarchy allows going beyond the dichotomy of hierarch and horizontality. Heterarchy suggests that elements, in this case of the alterglobalization movements, and issues can be ranked as well as unranked in a number of different ways, depending on the context.

This innovative organizational principle was substantially toned down in favor of horizontality in the case of the alter-globalization movement in general and the social forum process in particular. The crowding out of heterarchy and with it hierarchical possibilities, I suggest, takes away from the political impact of the Global Social Forum Rhizome, lending itself to a politics that favors 'form over function'. The politics then often does not go beyond networking or 'protest swarming' on the summits of the global powers. Consequently, the Global Social Forum Rhizome espouses, from my point of view, a somewhat romantic notion of change.

\section{Notes}

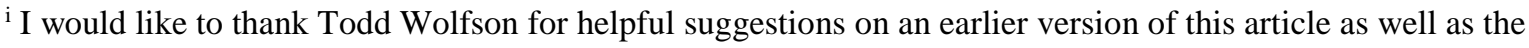
two anonymous reviewers for insightful and constructive comments and Ruth Reitan for her editorial guidance. Moreover, I would like to acknowledge the support of the University of South Florida's Research \& Development Grant. 
ii The exact number of World Social Forum editions depends on how one counts. So far, eight centralized World Social Forums have been organized with four forums in Porto Alegre (Brazil) 2001-2003, 2005 and one forum in Mumbai (India) 2004, Nairobi (Kenya) 2007, Belém (Brazil) 2009 and Dakar (Senegal) 2011 in addition to one polycentric World Social Forum in 2006 at three different locations (Bamako (Mali), Caracas (Venezuela), Karatchi (Pakistan) and two decentralized World Social Forums at no particular place but rather with various forums or activities taking place around the globe in 2008 and 2010.

iii Starting with the first European Social Forum in Florence (2002), first Asian Social Forum in Hyderabad (2003), first Social Forum of the Americas in Quito (2004), and the first African Social Forum in Conakry (2004). The European Social Forums have drawn the largest number of participants: Florence 2002: 60,000; Paris 2003: 70,000; London 2004: 50,000; Athens 2006: 35,000.

iv The German organizers decided to call it 'Social Forum in Germany' instead of 'German Social Forum' to indicate the non-national character of the forum.

${ }^{v}$ http://www.forumsocialmundial.org.br/dinamic/main.php?id_menu=11\&cd_language=2

vi The International Council (IC) is the permanent body of the World Social Forum in which over 150 movements and organizations are represented. The IC assumes political and operational responsibility of the World Social Forum.

vii See also: Janet Conway 2008.

viii See Funke 2010 and 2012 (forthcoming \& under review).

${ }^{\text {ix }}$ I use the term alter-globalization to indicate that the vast majority of movements and groups I refer to are not against global integration but against the neoliberal form of globalization. Other labels that are used include, the global justice movement, alternative globalization movement, globalization from below, movement of movements or anti-globalization movement.

$\mathrm{x}$ 'Resilience' as a concept has been gaining attention in the social sciences in the last decade. While curiously absent from political science, it has been adapted from ecological studies, which focuses research on processes of change and multiple equilibria. One of the key insights from ecological studies is the emphasis on diversity (of or instance plants) for resilience when encountering and reacting to an external shock (such as for instance a forest fire). While this study is not elaborating the concept of resilience for social forums and social movements, it suggests a fruitful future research angel. On 'resilience' see for instance: Berkes and Folke, 2000, Vale and Campanella, 2005, Swanstrom, Chapple and Immergluck, 2009. ${ }^{x i}$ See: Funke 2008, 2012 (forthcoming \& under review).

xii For a historical account of the World Social Forum see Leite 2003.

xiii The editors claim that the one no many yeses seems to have originated in the Mexican anti-nuclear movement in the early 1980s.

xiv It is interesting to note that the Zapatistas are not welcomed at the World Social Forum. The reason for this is their rejection of signing onto the non-violence imperative of the Charter of Principles of the World Social Forum. Recently, however, the Zapatista have been advocating non-violent democratic politics as the basis for direct action, stressing that violence is not the only path to democracy. See on this also: Abramsky 2001; Midnight Notes Collective, 2001; Notes from Nowhere, 2003.

${ }^{\mathrm{xv}}$ See for example Nash, 2003, Berger, 2004. There are certainly exceptions such as the radical wings of Third Worldism. See for example Elbaum 2002 cited in Olesen 2004.

xvi On the transition from Third World Solidarity to global solidarity including a more reciprocal relationship see Olesen 2004.

xvii The 2005 World Social Forum encompassed around 7,000 events and 155,000 participants. In 2006 the World Social Forum gathering in Bamako (Mali) is estimated to having been attended by 11,000 participants while 80,000 people participated in Caracas. The 2007 World Social Forum in Nairobi attracted less participants, 'official’ numbers putting participants at 60,000. The 2011 World Social Forum took place with roughly 75,000 participants and 1,200 events. Estimates come form the Forum's webpage at http://www.forumsocialmundial.org.br and are considered quite conservative by other observers.

xviii http://www.tni.org/detail_page.phtml?\&text10=newpol-docs_eurotopia\&menu=11f

xix http://www.fsivry.free.fr/index.htm

${ }^{\mathrm{xx}}$ On protest cycles see: Tarrow, 1998.

xxi 'Fantasia Variations' reiterates and incorporate material even more freely than 'variations'.

xxii The rhizome as epistemological perspective will not be pursued in this article but is part of the author's work in progress. 
xxiii Principle 1 of the World Social Forum Charter of Principles; online at:

http://www.forumsocialmundial.org.br/dinamic/main.php?id_menu=4\&cd_language=2 .

xxiv Interview with Manfred Brinkmann, Koordinator DGB Bildungswerk [coordinator political education department of the Confederation of German Trade Unions , Frankfurt (Germany) 12 September 2006.

xxv Interview with Philip Hersel (Blue 21), Berlin 25 August 2006.

${ }^{x x v i}$ For a more detailed discussion of this case see: Funke (under review).

xxvii Ver.di is the abbreviation for Vereinte Dienstleistungsgewerkschaft, (United Services Union). Ver.di is one of the largest individual trade unions in the world with roughly 2.4 million members. It organizes employees in over 1,000 different trades and professions. See:

http://international.verdi.de/ver.di_fremdsprachig/was_ist_ver.di_-_eine_einfuehrung_auf_englisch

xxviii See for instance: Hamann 2006.

${ }^{\text {xxix }}$ Achim Neumann (Ver.di; ESF participant and workshop organizer), interview, Berlin 27 June 2006.

xxx Comment by Anne Norton on an earlier draft of this part.

xxxi Italics in original.

xxxii See: Funke 2010, 2012 (forthcoming \& under review).

xxxiii See: Funke 2010.

xxxiv Todd Wolfson aptly labels them 'Cyber Left', capturing 'the shape of [this] globalized, digitized, radically democratic, network formation' and the way contemporary movements and groups use-often electronic-communication to forge connections (Wolfson, p. 3). Similarly, Richard J. F. Day, argues that contemporary movements are different. Day's 'newest social movements', are distinct from the Old Left and New Left in that there 'is no single enemy against which the newest social movements are fighting. Rather, there is a disparate set of struggles, each of which needs to be addressed in its particularity [but] I will refer to the neoliberal project as providing a shared background or context within which they occur' (Day, p. 6, italics in original).

\section{References}

Abramsky, K. (ed) (2001) Restructuring and Resistance: Diverse Voices of Struggle in Western Europe (London: ResResRev).

Bahn, E. \& Haberland, M. (2003) Projektbericht: Initiative für ein Berliner Sozial Forum, Projektkurs Soziale Bewegungen und außerinstitutionelle Initiativen in Berlin (Freie Universität Berlin, Otto Suhr Institut).

Berger, M. T. (2004) After the Third World? History, destiny and the fate of Third Worldism, Third World Quarterly, 25(1), pp. 9-30.

Berkes, F. \& Folke, C. (2000) Linking Social and Ecological Systems of Resilience and Sustainability” in: F. Berkes \& C. Folkes (eds) Linking Social and Ecological Systems: Management Practices and Social Mechanisms for Building Resilience (New York: Cambridge University Press), pp. 1-25.

Biagiotti, I. (2004) The World Social Forums. A paradoxical application of participatory Doctrine, International Social Science Journal, 56(182), pp. 529-540.

Blau, J. \& Karides, M. (eds.) The World and US Social Forums: A Better World is Possible and Necessary (New York: Lexington Books).

Burbach, R. (2001) Globalization and Postmodern Politics: From Zapatistas to High Tech Robber Barons (London: Pluto Press).

Cassen, B. (2003) On the Attack, New Left Review 19, January/February, pp. 41-60.

Conway, J. (2005) The empire, the movement, and the politics of scale: Considering the World Social Forum, Paper prepared for 'Towards a Political Economy of Scale: Studies in the Political Economy Conference', York University, February 3-5, 
online at: http://www.openspaceforum.net/twiki/tiki-

read_article.php?articleId=159;

Conway, J. (2005) Social Forums, Social Movements and Social Change: A Response to Peter Marcuse on the Subject of the World Social Forum, International Journal of Urban and Regional Research, 29(2), pp. 425-428.

Conway, J. (2008) Reading Nairobi: Place, Space, and Difference at the 2007 World Social Forum, Societies Without Borders 3, pp. 48-71.

Cox, R. (1981) Social Forces, States and World Orders: Beyond International Relations Theory, Millennium: Journal of International Studies, 10(2), pp. 126-155.

Day, R. J. F. (2005) Gramsci Is Dead: Anarchist Currents in the Newest Social Movements (London: Pluto Press).

Deleuze, G. \& Guattari, F. (1980) A Thousand Plateaus: Capitalism and Schizophrenia (Paris: Minuit).

Dyer-Witheford, N. (1999) Cyber-Marx: Cycles and Circuits of Struggle in HighTechnology Capitalism (Chicago: University of Illinois).

Ehrenreich, R., Crumley, M., Carole L. \& Levy, J.E. (eds) (1995) Heterarchy and the Analysis of Complex Societies (Chapel Hill: University of North Carolina Press).

Elbaum, M. (2002) Revolution in the Air: Sixties Radicals turn to Lenin, Mao and Che (London: Verso).

Epstein, B. (1991). Political Protest and Cultural Revolution: Nonviolent Direct Action in the 1970s and 1980s (Berkeley and Los Angeles: University of California Press).

Escobar, A. (2004) Other Worlds Are (Already) Possible: Self-Organisation, Complexity, and Post-Capitalist Cultures, in J. Sen, A. Anand, A. Escobar \& P. Waterman (eds) The World Social Forum: Challenging Empires (New Dehli: Viveka), pp. 122-129.

Fisher, W.F. \& Ponniah, T. (eds.) (2003) Another World is Possible: Popular Alternatives to Globalization at the World Social Forum (London: Zed Books).

Funke, P.N. (2008) The World Social Forum: Social Forums as Resistance Relays, New Political Science: A Journal of Politics and Culture, 30(4), pp. 449-474.

Funke, P. N. (2012) The Rhizomatic Left and Neoliberal Capitalism: Theoretical Interventions on Contemporary Social Movements in the Global North, International Critical Thought. 2(1), (forthcoming).

Funke, P.N. (under review) The World Social Forum As Resistance Relay: Building a Global Movement?

Funke, P.N., Robé, C. \& Wolfson, T. (forthcoming). Suturing Working Class Subjectivities: Media Mobilizing Project and the role of Media in Building a Classbased Social Movement, tripeC Cognition, Communication, Co-operation.

Gimenez, M. E. (2005) Capitalism and the Oppression of Women: Marx Revisited, Science and Society. 69, pp. 11-32.

Hamann, A. \& Giese, G. (2006) The Black Book on Lidl in Europe: Schwarz Retail Company: Selling cheap at the employees' expense. Berlin: Vereinte Dienstleistungsgewerksachft ver.di, UNI Commerce). Retrieved from: http://www.unionnetwork.org/UNISITE/Sectors/Commerce/Multinationals/Lidl_Bl ack_Book_in_English.htm

Hardt, M. (2002) Today’s Bandung? A Movement of Movements? New Left Review, 14, March-April, pp. 112-118. 
Harvey, D. (1996) Justice, Nature and the Geography of Difference (New York: Blackwell).

Harvey, D. (2005/2007) A Brief History of Neoliberalism (New York: Oxford University Press, USA).

Leite, J.C. (2003) The World Social Forum: Strategies of Resistance (Chicago: Haymarket Books).

Lorenzano, L. (1998) Zapatismo: Recomposition of Labour, Radical Democracy and Revolutionary Project, in J. Holloway \& E. Pelaez (eds) Zapatista! Reinventing Revolution in Mexico (London: Pluto Press).

Midnight Notes (1998) One No Many Yeses, in Introduction to Midnight Notes 12 (Leeds: Autonomedia0.

Midnight Notes Collective (2001) Introduction: The Hammer ... or the Sickle? From the Zapatista Uprising to the Battle of Seattle, in Midnight Notes (eds) Auroras of the Zapatistas: Local \& Global Struggles of the Fourth World War (Leeds: Autonomedia).

Nash, A. (2003) Third Worldism: Address to the Annual Congress of the South African Sociological Association 2001, African Sociological Review 7(1), pp. 91-116.

Notes from Nowhere (2003) We Are Everywhere: The Irresistible Rise of Global Anticapitalism (London: Verso).

Nunes, R. (2006) Nothing is What Democracy Looks Like: Openness, Horizontality and The Movements of Movements, in D. Harvie, K. Milburn, B. Trott \& D. Watts (eds) Shut them Down! The G8, Gleneagles 2005 and the Movement of Movements (Leeds: Dissent! and New York: Autonomedia), pp. 299-319.

Olesen, T. (2004) From Third World Solidarity to Global Solidarity? Third World Quarterly, 25(1), pp. 255-267.

Pleyers, G. (2004) The Social Forum as an ideal model of convergence International Social Science Journal, 56(182), pp. 507-517.

Ramonet, I. (1995) La pensée unique, Le Mond Diplomatique, January, online at: http://www.monde-diplomatique.fr/1995/01/RAMONET/1144

Reitan, R. (2007) Global Activism (London: Routledge).

Ruth R. (2011) Coordinated Power in Contemporary Leftist Activism, in: T Olesen (ed) Power and Transnational Activism (London and New York: Routledge).

Sen, J., Anand, A., Escobar, A., Waterman, P. (eds.) (2008) The World Social Forum: Challenging Empires (London: Black Rose Books).

Smith, J., Karides, M., Becker, M., Brunelle, D. Chase-Dunn, C., Porta, D. Garca, R. I., Juris, J., Reese, E. Smith, P. Vazquez, R. (eds.) (2008) Global Democracy and the World Social Forum (Boulder, CO: Paradigm Publishers).

Sousa Santos, B. (2006) The Rise of the Global Left: The World Social Forum and Beyond (London: Zed Books).

Swanstrom, T., Chapple, K. \& Immergluck, D. (2009) Regional Resilience in the Face of Foreclosure: Evidence from Six Metropolitan Areas, University of California Working Paper 05.

Tarrow, S. (1998) Power in Movement: Social Movements and Contentious Politics (Cambridge: Cambridge University Press).

Tarrow, S. (2005) The New Transnational Activism (Cambridge: Cambridge University 
Press).

Vale, L. J. \& Campanella, T. J. (eds) (2005) The Resilient City: How Modern Cities Recover from Disaster (New York: Oxford University Press).

Whitaker, F. (2002) World Social Forum: Origins and Aims, retrieved from: www.tni-archives.org/detail_page.phtml?page=socforum-docs_origins

Whitaker, F. (2007) Das Weltsozialforum: Offener Raum für eine andere Welt (Hamburg: VSA Verlag).

Williams, R. (1989) Resources of Hope: Culture, Democracy, Socialism (London: Verso). Wolfson,T. (2009) The Cyber Left: Indymedia and the Making of Twenty-first Century Struggle (University of Pennsylvania: Ph.D. Dissertation). 